\title{
Distribution of histological diagnoses of black and white skin in Campinas, diseases Brazil, from 1993 to 2009
}

\author{
Distribuição dos diagnósticos histológicos das afecções da pele negra \\ e branca, em Campinas, Brasil, entre 1993 e 2009
}

Isabela Mamere Alvarez'; Juliana Puggina²; Helymar C. Machado³; Rafael Fantelli Steliní;

Michelle Etienne Florence ${ }^{5}$ Elemir Macedo de Souza ${ }^{6}$; Maria Letícia Cintra ${ }^{7}$

\begin{abstract}
Introduction: Little is known about ethnic differences in the frequency of skin diseases, and even less in terms of Brazilian population, which is characterized by miscegenation. Objective: To evaluate the distribution of skin disorders in black and Caucasian patients through pathological specimens. Methods: 826 biopsies from black-skinned individuals and 1,652 from white-skinned patients were retrieved and studied from the files of the Pathology Department, UNICAMP Hospital within the period of 1993-2009. The clinical data were obtained from medical records and the results were tested by statistical methods. Results: Non-melanoma cancer was the most frequent diagnosis in Caucasians (45\%), differing from the frequency among black patients $(8 \%)$, both arising in sun-exposed skin. Regarding topography and age, in white-skinned patients aged over 50 years, biopsies of "head and neck" prevailed. As to black patients, the disease predominated among female individuals aged from 15 to 50 years and in the genital area. In the comparative analysis of vulvar diseases, we observed differences in diagnoses of sexually transmitted diseases more common among black women. Excluding cancers and genital lesions, black patients had a higher percentage of infectious diseases. Among the non-infectious diseases, cutaneous lupus was the most frequent diagnosis in both groups. Lichen planus and drug reactions were more frequent in black patients. Conclusion: Apart from intrinsic differences among skin types, social factors may interfere in the distribution of diseases. Not only may these results be useful to public health programs, but they may also aid the approach to dermatological diseases in black skin patients.
\end{abstract}

Key words: pathology; race; color; biopsy; skin; dermatologic diseases.

\section{INTRODUCTION}

Cutaneous manifestations of most diseases are described in patients with fair skin, but few publications characterize them in black skin. As the degree of pigmentation interferes significantly in the semiological approach to cutaneous diseases, the recognition of dermatitis in darker skin may constitute a challenge in daily medical practice ${ }^{(1)}$. Additionally, changes in black skin may be difficult to diagnose due to variations in the clinical presentation. Moreover, certain diseases only arise in colored skin. Among particular black skin diseases, those resulting from the use of lightener products are particularly

First submission on 04/02/13; last submission on 12/06/13; accepted for publication on 13/06/13; published on 20/08/13

1. Research student from the Research Grant Program (Programa Institucional de Bolsas de Iniciação Científica [PIBIC])/National Council for Scientific and Technological Development (Conselho Nacional de Desenvolvimento Científico e Tecnológico [CNPq]); graduate student at Universidade Estadual de Campinas-Medical School (UNICAMP).

2. Resident at Universidade de São Paulo-Medical School-Clinical Hospital (USP)

3. Statistician at the Research Committee of UNICAMP.

4.Pathologist; assistant doctor at the Department of Pathology of UNICAMP.

5. Dermatologist; assistant doctor at the Dermatology Department of Internal Medicine of UNICAMP.

6. Associate professor in Dermatology at the Dermatology Department of Internal Medicine of UNICAMP.

7. Associate professor at the Department of Pathology of UNICAMP. 
worth mentioning ${ }^{(3)}$. Hyperpigmentation also complicates the diagnosis of certain diseases by masking clinical manifestations such as erythema ${ }^{(4)}$. In cutaneous inflammatory diseases, chemical mediators such as leukotriene and prostaglandins ${ }^{(6)}$ are released, which activate melanocytes, hence increasing melanin synthesis. This is one of the events that justifies the post inflammatory hyperpigmentation, more prevalent in dark-skinned individuals in comparison with Caucasians ${ }^{(6)}$. Due to the high degree of miscegenation in the Brazilian population, the identification of who might be called black is inaccurate, prevailing, for statistical purposes, the criterion of selfdeclaration ${ }^{(1)}$. According to Parra et al., the physical appearance is often used for racial definition and prejudice ${ }^{(19)}$. Instead of ancestry, skin color is related to the concept of race in Brazil. Thus, some authors classify the Brazilian population into groups of skin color, but not races ${ }^{(13)}$. The human species has been classified into subspecies or races: Caucasoid, Mongoloid, Negroid or Congoid, and Capoid Australoid ${ }^{(24)}$. Based on this system, Brazilians form one of the most heterogeneous populations in the world, inasmuch as they are the result of centuries of inter-ethnic relations of people from three continents: European settlers (mostly Portuguese), African slaves and autochthonous Amerindians.

Would a comparative study of skin diseases in white and dark skinned individuals in our country, notorious for its genetic mixing, reveal similar results to those conducted in Europe and North America? On clinical grounds, a study conducted in the USA concluded that acne, dyschromia, eczema, seborrheic dermatitis and alopecia were the most common dermatologic diagnoses in black-skinned individuals. Acne, benign skin neoplasia, dermatitis, eczema, and psoriasis were found in white-skinned patients ${ }^{(2)}$. In another study developed in Paris, it was concluded that both white and dark-skinned people seek dermatologists for treating benign skin conditions. The authors studied 836 patients and the diagnoses were acne, eczema, and alopecia in $29.2 \%$ of black adults ${ }^{(3)}$.

Although pigmentation is an important factor that infers in the type of disease an individual will develop, heredity and extrinsic factors (nutrition, socioeconomic status, education, occupation and environment) also affect the manifestation and course of several skin diseases ${ }^{(16)}$.

The statistic results of the global population show a predominance of dark-skinned people. Accordingly, the dermatological community deals with diseases that may occur more frequently or be present in an unusual or unique way in people with pigmented skin ${ }^{(24)}$.

There are few studies on the characteristic features of dermatological diseases in black skin, mainly regarding non-neoplastic ones, and most of them were not conducted through biopsies. Those studies do not address the differences between skin color groups, mainly those concerning diseases in which there is an indication for biopsy in order to substantiate the hypothesis postulated on clinical basis. At first, we studied the distribution of all histological diagnoses of skin diseases according to skin color, age, gender and topographic location of lesions over a 16 -year period ${ }^{(21)}$. Subsequently, we approached the particularities of the diagnoses in the vulvar region ${ }^{(20)}$ and, finally, all inflammatory diseases in both skin color groups.

\section{METHODS}

The information on all skin biopsies collected from individuals categorized as black and white (either by the individual responsible for the admission, or by the dermatologist who assessed the patients) was retrieved from the archives of the Pathology Department from July 1993 to December 2009. Biopsies from those classified as Asian and Mulattos were excluded. All pathological reports stating "only microscopic description", "normal" or "inappropriate/inadequate specimen for analysis" were excluded. Afterwards, only one biopsy was randomly selected per individual, as long as it was in the same topography, with the same histological diagnosis and the same year of occurrence. Finally, 1,113 biopsies of black-skinned and 31,352 of white-skinned individuals were selected. After applying the inclusion and exclusion criteria, 826 biopsies of black-skinned individuals were included. The same criteria were applied to the group of white-skinned patients. Thus, a sample of 1,652 biopsies of white-skinned individuals were randomly selected, totaling 2,478 specimens. For tabulation purposes, the anatomical region from where the biopsy was collected and their respective diagnoses, as detailed in the medical files, were aggregated into groups. Subsequently, in the group of inflammatory skin diseases, all clinical records of each black-skinned patient and the random sample of paired white-skinned patients were reviewed. The purpose was to identify the nosological diagnoses (obtained by summing the semiology, follow-up/therapeutic response, culture, biopsy, serological tests, and image). All data were recorded on a standardized form. Socioeconomic and education levels were not included in the protocol for data collection from medical records. All patients were admitted at the National Health System (SUS). The statistical method used for comparative bi-varied analysis was the chi-square test for nonparametric variables, based on data retrieved from biopsies from the total population of black patients and a paired sample of valid random biopsies from white patients. Values at $p<0.05$ were considered statistically significant. 
This study was approved by the Research Ethics Committee of the Faculty of Medical Sciences, University of Campinas.

\section{RESULTS}

Median age of white-skinned patients was higher in comparison with black-skinned individuals, but when cancers were excluded from the analysis, there were no differences. The frequency of the following diseases was statistically different between groups: malignancies were more frequent among white patients (45\% of diagnoses among white-skinned and $8 \%$ among black-skinned patients); keloids, infectious diseases and diseases of the vulva were more frequent among black patients. Eight percent of biopsies from black-skinned patients were malignancies, and four basal cell carcinomas were found. By excluding malignancies, which were much more common in Caucasians, and repeating the comparative analysis, the difference as to "infectious diseases" remained, which were more common in black-skinned patients $(p<0.001)$. Furthermore, there was significant difference $(\phi<0.0001)$ as to melanocytic nevi $(15 \%$ of lesions of white-skinned and $6 \%$ of black-skinned patients). Confronting the variables "gender" and "diagnosis" in the two skin color groups, there was a predominance of malignant neoplasms among white-skinned men in relation to women of the same group and malignancies were more frequent in the "head and neck" topography. Table and Figure illustrate the distribution of the diseases in this study.

The age of white and black patients with removed melanocytic nevi was similar, averaging 39 years. As to lesion topography, there was a statistical difference in the acral nevi group, more frequent

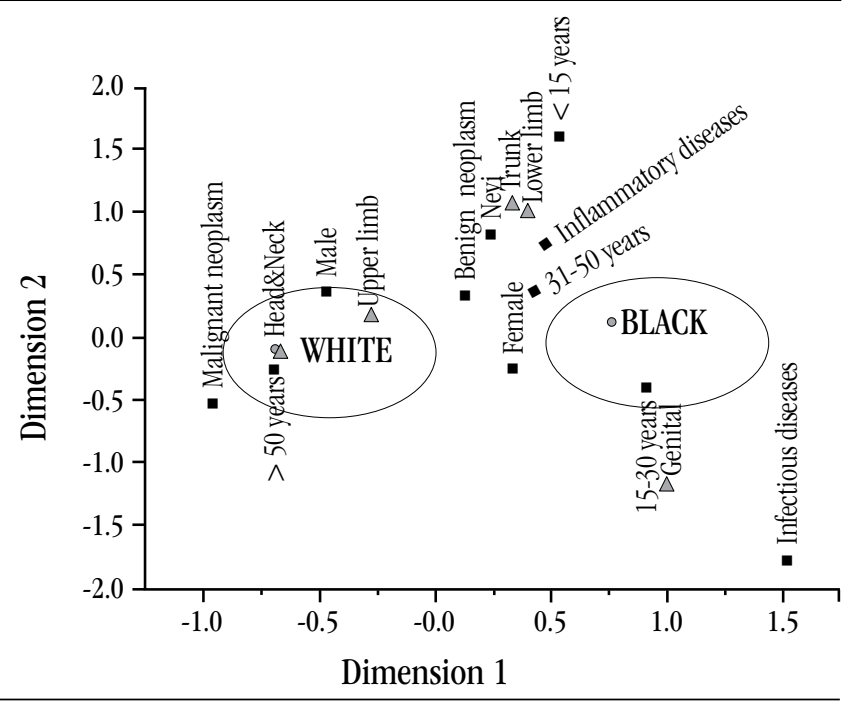

FIGURE - Distribution of the diseases in white and black patients
TABLE - The distribution of the diseases in white and black patients

\begin{tabular}{lccc}
\hline \multicolumn{1}{c}{ Diagnosis } & $\begin{array}{c}\text { White } \\
(\%)\end{array}$ & $\begin{array}{c}\text { Black } \\
(\%)\end{array}$ & $p$ \\
\hline Benign neoplasias & 12.3 & 15.4 & - \\
Malignant neoplasias & 45.6 & 8.0 & $<0.001$ \\
Melanocytic nevus & 8.5 & 5.8 & - \\
Fibrosing diseases & 3.9 & 8.8 & - \\
Keloid & 0.2 & 3.2 & $<0.001$ \\
Dyschromia & 0 & 0.6 & - \\
Non-infectious inflammatory & 20.9 & 43.9 & $<0.001$ \\
diseases & 2.4 & 10.8 & $<0.001$ \\
Infectious diseases & 6.4 & 6.7 & - \\
Other & & & \\
\hline
\end{tabular}

Chi-square test.

in black patients. Blue nevi were more common in black patients and dysplastic nevi were detected only in white patients.

In the comparative analysis of vulvar diseases, as previously reported ${ }^{(20)}$, it was observed that $65 \%$ of black skin lesions versus $36 \%$ of white lesions resulted from sexually transmitted infections $(p<0.001)$. Condyloma acuminatum was identified in 55\% of black-skinned patients and 36\% of white-skinned patients $(\phi=0.019)$. Nonspecific chronic inflammation was recorded in $36 \%$ of black and $21 \%$ of white-skinned patients $(p=0.032)$, and invasive squamous cell carcinoma in $9 \%$ of white and in none of the black-skinned patients $(\phi=0.017)$. Inflammatory diseases at locations other than vulva were grouped into "infectious, collagen diseases, eczematous, other noninfectious inflammatory and miscellaneous". In both groups, noninfectious inflammatory lesions predominated, including alopecia, atopic dermatitis, erythema nodosum, drug eruption, lichenoid dermatitis, pemphigus, psoriasis and urticaria. Statistical difference was identified in the infectious diseases and eczema (25\% atopic dermatitis) groups, which prevailed in black patients. The frequency of leprosy was high in both groups: $6.8 \%$ in black and $4.7 \%$ in white patients, $70 \%$ of patients were male, $58 \%$ of whom were black. We also encountered significant differences in the frequency of adverse drug reactions (10\% in black and 4\% in white patients), and lichen planus ( $6 \%$ in white and $0.7 \%$ in black patients). The frequency of psoriasis was similar in both groups $(5.3 \%$ in white and $4 \%$ in black patients). Collagen diseases were particularly noteworthy, which corresponded to $15 \%$ of the diseases in the white population and $14 \%$ in the black population. Among the collagen diseases, lupus was the most frequent (11\% in white and $8 \%$ in black patients), predominantly in women (2:1 ratio among black and 4:1 among white patients). When nosological diagnoses were not defined, even after clinical/laboratorial evaluation and follow up, the processes were recorded as "nonspecific chronic dermatitis", as described in 
the pathologic report. They represented $9.5 \%$ of the diagnoses from black patients' biopsies and $6.6 \%$ of white patients' biopsies.

\section{DISCUSSION}

The Brazilian population is among the most heterogeneous in the world ${ }^{(19)}$. To define race, individual physical traits such as skin pigmentation, color/hair structure and shape of the nose/lips are normally employed. Although the color is the most important racial difference, it is only one piece of the biological mosaic. Anthropologists and geneticists assert that, from a biological standpoint, human races do not exist ${ }^{(18)}$. Whatever the viewpoint is, in Brazil, it is claimed that people cannot be classified into different races, but rather into groups of different skin tones. The University Outpatient Clinics admit daily more than 2000 NHS patients from the metropolitan area of the city as well as other parts of the State of São Paulo and neighboring states. Many fair-skinned patients, mostly Italian descendants, develop activities related to agriculture and lack resources for effective photoprotection, thus presenting chronic photo damage. Black patients, African descendants brought to the farms in the area, present natural protection to the ultra-violet rays. Therefore, they are less prone to skin cancer. Additionally, in the last two decades, due to the region's economic growth, there has been remarkable migration of individuals from other States of the country. It has been demonstrated ${ }^{(10,12)}$ that black skin displays particularities that must be considered when examining lesions in different diseases. The cutaneous manifestations of a single disease may differ between black and white skins. Additionally, some skin conditions occur almost exclusively in black patients. Moreover, common diseases may have an atypical presentation in black-skinned patients, as the clinical signs are attenuated by the pigment. Apart from skin color, other genetic, environmental, socio-economic and cultural aspects may influence the distribution and frequency of the diseases ${ }^{(18)}$. This study showed no differences between the two groups of skin color in terms of age (mean age in the fourth decade). However, when the tumors were included, the average age of the white population increased from 40 to 54 years, whereas in the black population it remained 40 years. This result is anticipated given that the occurrence of neoplastic skin lesions is directly related to sun exposure, skin type and chronological age $e^{(14,15)}$.

The analysis of all pathological diagnoses revealed the predominance of "head and neck" topography in white patients and genital topography in black patients. Nevertheless, when neoplasms were excluded, the topographic distribution of the lesions in white and black individuals became more homogeneous. This finding corroborates the photoprotection exerted by melanin ${ }^{(15)}$ and points to the greater vulnerability of black-skinned people to the development of diseases linked to unfavorable economic and social situations, namely the greater frequency of sexually transmitted diseases in women. The depletion of the ozone layer has exacerbated the harmful effects of ultraviolet radiation in the world population. Thus, even individuals of pigmented skin increasingly need to avoid sun exposure ${ }^{(5)}$. In black patients, the protection afforded by melanin provides a false sense of security. In fact, in the sample studied, $8 \%$ of the biopsies of black-skinned patients were malignancies, all in sun-exposed areas, and four of them were basal cell carcinomas. As this cancer is rare in black patients, there is a delay in the diagnosis. Therefore, it should be included in the differential diagnosis of any suspicious lesion in black patients in order to prevent morbidity resulting from delayed diagnosis ${ }^{(5)}$. By means of using the exclusion of malignancies (evidently more common in white patients, changing the significance of the other groups) as a statistical strategy, a significant difference was observed between the groups as to melanocytic nevi, which was higher in white patients. Ultraviolet radiation is the most common environmental stimulus in melanocytic proliferation, being involved in both the genesis of new nevi and their disappearance in adult life ${ }^{(8)}$. Nevi are found in higher concentration in exposed areas. Thus, the prevalence increases with age until the third decade due to sun exposure since childhood. Nevi are rare in Asians and black patients, but they are more frequent in the palms and soles when present. Apart from skin color, genetic factors also interfere in their genesis. In this sample, most nevi in black-skinned patients were congenital, very pigmented, and usually acral, with statistical difference in relation to nevi in white patients. The largest ones (mostly less than $5 \mathrm{~cm}$ ) were removed to avoid malignancy. In fact, only some nevi that arise in blackskinned patients are removed due to the reasons described above. Most nevi in Caucasians are never removed, which modifies the comparative frequency on biopsy material. In sum, the findings are consistent with what has been described in the literature: nevi are rare in dark-skinned patients and they are more frequent in the acral region when present among them ${ }^{(8)}$.

Analyzing the distribution of inflammatory diseases, we observed a higher frequency of infectious diseases and eczema in the black population in comparison with white patients. Regarding infectious diseases, leprosy presented high frequency in both groups, which is closely related to indicators such as low family or per capita income, poor education and lack of basic health conditions. Malnutrition or some nutritional deficiencies and poor hygienic conditions are unfavorable factors associated with disease transmission. Considering the skin color, a Brazilian study demonstrated that 
black men are $1.6 \%$ more likely to acquire the disease ${ }^{(22)}$. In this study, $70 \%$ of leprosy patients were male and $58 \%$ were black.

In an American study, eczema was more frequently diagnosed in black individuals ${ }^{(26)}$, which is in agreement with the results yielded herein. In Africa, eczema proved to be the main dermatological disease diagnosed in the population ${ }^{(11)}$. In general, there is no perceptible erythema in dark skin, hence its rapid progression to dyschromia. Acute forms with blistering and exuding are more common in Caucasians. Pigment changes and lichenification prevail in dark $\operatorname{skin}^{(11)}$. Among collagen diseases, lupus was the most prevalent. Our results are supported by most studies: the disease prevails in females at 2:1 ratio and affects any skin color in similar proportions ${ }^{(7)}$. Clinical expressions vary in different ethnic groups: black patients present mainly malar rash and photosensitivity, whereas livedo reticularis is less common $^{(9)}$. As far as non-infectious inflammatory diseases are concerned, the drug eruption was the most frequent diagnosis in the blackskinned group and the second in Caucasians. Moreover, there was significant difference in the frequency between the two groups. However, the results of a previous study, also performed in São Paulo State, were different: $86 \%$ of patients were white and $4.7 \%$ were black ${ }^{(23)}$. The difference may be accounted for the way the patients were evaluated. Our patients were investigated according to skin color, paired in groups, and only included when the disease was analyzed through biopsy. Lichen planus also exhibited a significant difference in the frequencies, with few cases from black patients in the sample. Nevertheless, the literature indicates that this is a common disease in dark skin, characterized by bright, dark or grayish lesions, being the annular form the most frequent. A USA study showed racial predominance of lichen planus in the pediatric population: $72 \%$ of the children were African-American and personal or family history of autoimmune disease was present in $17 \%$ of patients ${ }^{(25)}$, which was not observed in our sample, inasmuch as it comprised only pathological analysis. Regarding psoriasis, although the disease is less common in black than in white patients, it is not uncommon in any of the groups. Its lower frequency in black-skinned individuals is probably related to genetic factors ${ }^{(17)}$. The similarity in frequency of psoriasis may be attributed to the miscegenation of the Brazilian population.

The difference observed in the number of "nonspecific chronic dermatitis", more frequent in black skin, deserves attention, insofar as it may result from the difficulty in diagnosing skin diseases in dark skin. It is important to highlight that all results presented herein are related to skin lesions that were necessarily investigated through pathological examination. Accordingly, the frequency of certain diseases may be underestimated, namely acne ${ }^{(1,3,4)}$, which is common in the black population, but in most cases is not investigated through pathological examination.

\section{CONCLUSION}

In this mixed population, considering only the variable "skin color", part of the differences detected between the groups in the frequency of dermatological diseases is similar to the results described in Anglo-Saxon countries. Social and genetic factors (miscegenation) are probably associated with other differences. These results may be helpful to the medical practice and public health programs.

\section{ACKNOWLEDGEMENTS}

This paper was sponsored by CNPq and São Paulo Research Foundation (FAPESP).

\section{RESUMO}

Introdução: Pouco se conhece sobre as diferenças étnicas na frequência das doenças da pele e, menos ainda, na população brasileira, caracterizada pela miscigenação. Objetivo: Avaliar a distribuição das afecções da pele de indivíduos negros, comparativamente com a dos brancos, em material anatomopatológico. Métodos: Foram estudadas 826 biópsias de indivíduos de pele negra e 1.652 dos de pele branca, obtidas do Departamento de Anatomia Patológica do Hospital das Clínicas da Universidade Estadual de Campinas (HC-UNICAMP), entre 1993 e 2009. Os achados clínicos foram obtidos dos prontuários e os resultados testados por métodos estatísticos. Resultados: O câncer não melanoma foi o diagnóstico mais frequente nos brancos (45\%), diferindo, significantemente, da frequência nos negros (8\%), assestando-se, em ambos, na pele exposta ao sol. Quanto à topografia e à idade, nos brancos predominavam biópsias da "cabeça e pescoço", na faixa acima dos 50 anos. Nos negros, as doenças predominavam entre 15 e 50 anos, no sexo feminino, na topografia dos genitais. À análise comparativa das doenças vulvares, observou-se diferença nos diagnósticos de doenças sexualmente transmissiveis mais frequentes nas mulheres negras. Excluindo-se os cânceres e a topografia 
genital, os negros apresentaram porcentagem maior de doenças infecciosas. Entre as doenças não infecciosas, o lüpus cutâneo foi a mais frequente nos dois grupos; o líquen plano e a farmacodermia foram mais frequentes nos negros. Conclusão: Além das diferenças intrínsecas de tipos de pele, fatores sociais podem atuar na distribuição das doenças. Esses resultados podem ser úteis, tanto para os programas de saúde pública quanto para a abordagem das doenças dermatológicas nos pacientes de pele negra.

Unitermos: patologia; raça; cor; biópsia; pele; doenças dermatológicas.

\section{REFERENCES}

1. ALCHORNE, M. M.; DE ABREU, M. A. Dermatoses na pele negra. In: ROTTA, 0. Guia de dermatologia: clínica, cirúrgica e cosmiátrica. Barueri: Manole, 2008. Cap. 70; p. 593-608.

2. ALEXIS, A. F.; SERGAY, A. B.; TAYLOR, S. C. Common dermatologic disorders in skin of color: a comparative practice survey. Cutis, v. 80 , p. 387-94, 2007.

3. ARSOUZE, A. et al. Presenting skin disorders in black Afro-Caribbean patients: a multicentre study conducted in the Paris region. Ann Dermatol Venereol, v. 135, p. 177-82, 2008.

4. CHILD, F. J. et al. A study of the spectrum of skin disease occurring in a black population in south-east London. Br J Dermatol, v. 141, p. 512-7, 1999.

5. CHORUN, L.; NORRIS, J. E.; GUPTA, M. Basal cell carcinoma in blacks: a report of 15 cases. Ann Plast Surg, v. 33, p. 90-5, 1994.

6. DAVIS, E. C.; CALLENDER, V. D. Postinflammatory hyperpigmentation: a review of the epidemiology, clinical features, and treatment options in skin of color.J Clin Aesthet Dermatol, v. 3, p. 20-31, 2010.

7. DUARTE, A. A. Lúpus eritematoso cutâneo. An Bras Dermatol, v. 76, p. 655-71, 2001.

8. GALLAGHER, R. P.; MCLEAN, D. I. The epidemiology of acquired melanocytic nevi. A brief review. Dermatol Clin, v. 13, p. 595-603, 1995.

9. GEDALIA, A. et al. Childhood-onset systemic lupus erythematosus: a comparative study of African Americans and Latin Americans.J Natl Med Assoc, v. 91, p. 497-501, 1999.

10. HALDER, R. M.; NOOTHETI, P. K. Ethnic skin disorders overview. J Am Acad Dermatol, v. 48, 6 Suppl., p. S143-8, 2003.

11. HARTSHORNE, S. T. Dermatological disorders in Johannesburg, South Africa. Clin Exp Dermatol, v. 28, p. 661-5, 2003.

12. HENDERSON, A. L. Skin variations in blacks. Cutis, v. 32, p. 376-7, 1983 .

13. HERINGER, R. Desigualdades raciais no Brasil: síntese de indicadores e desafios no campo das políticas públicas. Cad Saúde Pública, v. 18, Suppl., p. 57-65, 2002.
14. HERZBERG, A. J.; DINEHART, S. M. Chronologic aging in black skin. Am J Dermatopathol, v. 11, p. 319-28, 1989.

15. KAIDBEY, K. H. et al. Photoprotection by melanin- a comparison of black and caucasian skin.J Am Acad Dermatol, v. 1, p. 249-60, 1979.

16. MCLAURIN, C. I. Unusual patterns of common dermatoses in blacks. Cutis, v. 32, p. 352-5, 1983.

17. NAMAZY, M. R. Why is psoriasis uncommon in Africans? The influence of dietary factors on the expression of psoriasis. Int J Dermatol, v. 43, p. 391-2, 2004.

18. PARRA, E. J.; KITTLES, R. A.; SHRIVER, M. D. Implications of correlations between skin color and genetic ancestry for biomedical research. Nat Genet, v. 36, 11 Suppl., p. S54-60, 2004.

19. PARRA, F. C. et al. Color and genomic ancestry in Brazilians. Proc Natl Adac Sci USA, v. 100, p. 177-82, 2003.

20. PUGGINA, J. et al. Comparison of vulvar skin diseases in black and white women: a histopathological study. J Eur Acad Dermatol Venereol, v. 22, p. 1391-2, 2008.

21. PUGGINA, J.; SOUZA, E. M.; CINTRA, M. L. Estudo comparativo da frequência dos diagnósticos histopatológicos das doenças de pele nas populações das raças negra e branca. In: Resumos do $62^{\circ}$ Congresso Brasileiro de Dermatologia, Anais Brasileiros de Dermatologia, Rio de Janeiro, 2007, v. 82, Suppl., p. 55-6.

22. SANTOS, A. S.; CASTRO, D. S.; FALQUETO, A. Fatores de risco para transmissão da hanseníase. Rev Bras Enferm, Brasília, v. 61, n. spe, 2008. Disponivel em: <http:/www.scielo.br/scielo.php?script=sci arttext\&pid=S0034-71672008000700014\&lng=en\&nrm=iso $>$. Acesso em: 3 fev. 2013.

23. SILVARES, M. R. et al. Reações cutâneas desencadeadas por drogas. An Bras Dermatol, v. 83, p. 227-32, 2008.

24. TAYLOR, S. C. Skin of color: biology, structure, function, and implications for dermatologic disease. J Am Acad Dermatol, v. 46, 2 Suppl. understanding, p. S41-61, 2002.

25. WALTON, K. E. et al. Childhood lichen planus: demographics of a U.S. population. Pediatr Dermatol, v. 27, p. 34-8, 2010.

26. WILLIAMS, H. C. Eczema across the world: the missing piece of the jigsaw reveled. J Invest Dermatol, v. 131, p. 12-4, 2011.

\section{MAILING ADDRESS}

